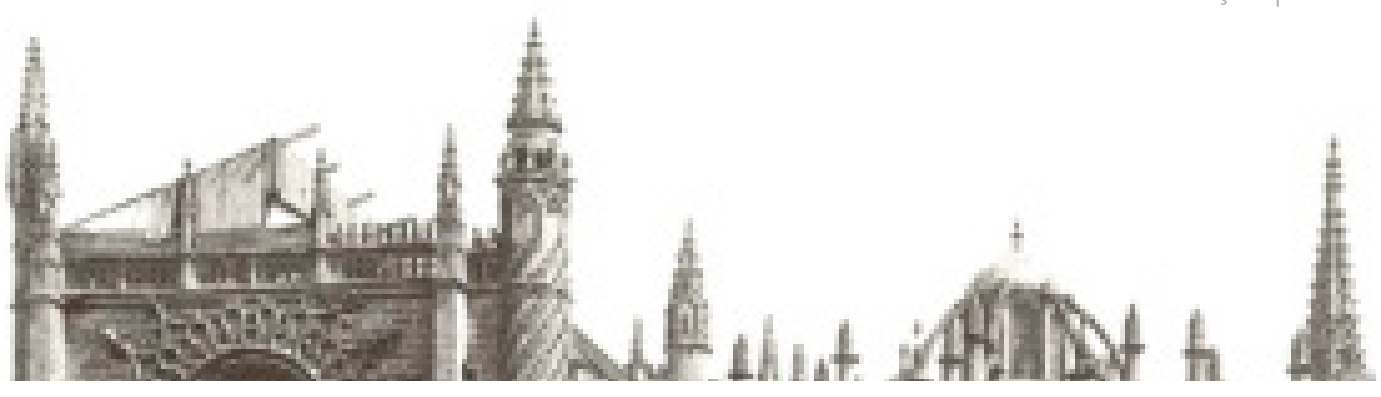

\title{
Electrochemical evaluation of the patina of the weathering steel sculpture Once Módulo
}

\author{
A. Crespo, B. Ramírez-Barat, I. Díaz, E. Cano
}

\begin{abstract}
Weathering steels (WS) have been widely used due to the protective rust formed on the surface of the bare metal exposed to the atmosphere. They have been studied attending to specifications and characteristics in engineering, but in cultural heritage the use of this material does not follow the same criteria and has different needs which must be addressed. Among them, the design and the location of the sculpture may have an impact on the rust formed and may not be as protective as it was supposed to be.

This work presents the study of the weathering steel sculpture Once Módulo which shows areas with different exposure to rainwater and different surface heterogeneities. The results obtained by Electrochemical Impedance Spectroscopy (EIS) have shown that the protective ability of the rust depends on the previous differences and that design and location of the artwork play an important role for its conservation.
\end{abstract}

Keywords: weathering Steel, sculpture, electrochemical impedance spectroscopy, atmospheric corrosion, conservation, contemporary art.

\section{Evaluación electroquímica de la pátina de la escultura en acero patinable Once Módulo}

Resumen: Los aceros patinables han sido ampliamente utilizados debido a la habilidad protectora de la herrumbre que se forma en la superficie del metal al exponerlo a la atmosfera. Su estudio se ha enfocado en las especificaciones y características desde un punto de vista ingenieril, sin embargo, en patrimonio cultural el uso de este material no sigue los mismos criterios y tiene distintas necesidades que han de atenderse. Entre ellas, el diseño y la localización de la escultura pueden tener un impacto en la herrumbre formada y esta puede no ser tan protectora como se supondría.

Este trabajo presenta el estudio de la escultura de acero patinable Once Módulo la cual muestra áreas con distinta exposición al agua de Iluvia y distintas heterogeneidades superficiales. Los resultados del análisis con Espectroscopia de Impedancia Electroquímica (EIE) han mostrado que la habilidad protectora de la herrumbre depende de las diferencias anteriores y que el diseño y la localización de la obra juegan un importante papel en su conservación.

Palabras clave: acero patinable, escultura, espectroscopia de impedancia electroquímica, corrosión atmosférica, conservación, arte contemporáneo

\section{Introduction}

Weathering steels (WS), also known by the commercial name Cor-Ten, are carbon steels with alloying elements such as chromium, copper and nickel in quantities lower than 3-5\% (Morcillo et al., 2013). WS are widely used in civil engineering due to their ability to naturally develop a protective patina at low aggressive atmospheres, which slows down the corrosion of the base metal and makes no need of painting the material (Díaz et al., 2012). Since the 1960s WS have also been used in contemporary art and architecture thanks to the rich colors of the patina and with the aim of placing outdoors sculptures which could remain even longer than bronze (Scott, 1991). However, there are some characteristics differences in the use of WS in cultural heritage compared to civil engineering that may modify and affect the protective ability of the rust.

The first difference is the use of acids and salts on the surface of the steel. As the appearance of the appealing patina needs long exposure times, sculptors and blacksmiths usually accelerate its formation with chemical treatments (Crespo, 2016). The second issue is the geometry of the sculpture, as one of the conditions for a patina to be 

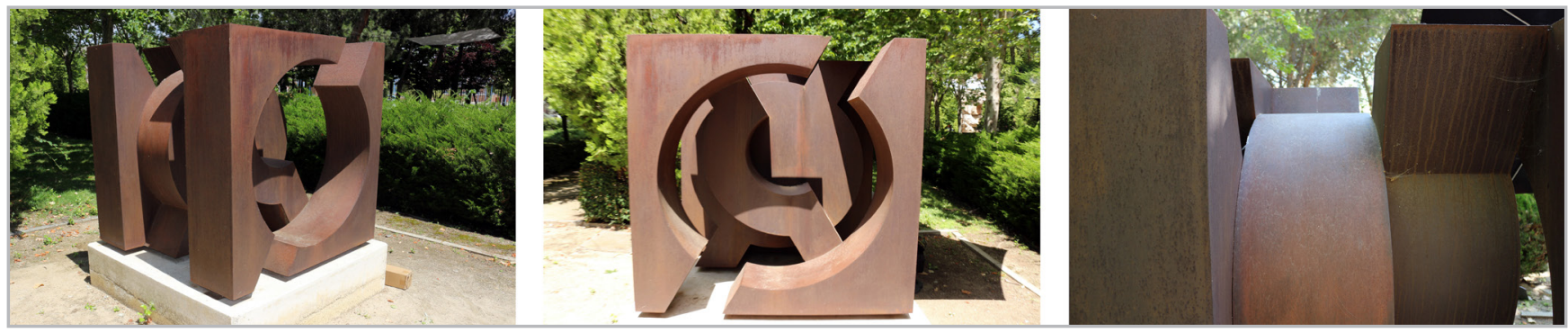

Figure 1.- Sculpture Once Módulo from different perspectives.

protective is the alternation of wetting and drying cycles (Stratmann et al., 1983), the design may have sheltered zones and water accumulation zones with different time of wetness (ToW: number of hours per year in which the relative humidity is higher than $80 \%$ and the temperature is beyond $0^{\circ} \mathrm{C}$, according to the ISO 9223). The last difference is the location of the artwork, if the artwork is constantly wet -as in parks with watering zones- or if is mainly dry as under a porch or trees- the wetting and drying cycles may be altered and have consequences on the protective ability of the rust. A good understanding of these effects is important to foresee the long-term durability of the artwork and contribute to its preservation.

The sculpture Once Módulo was performed by Amador Rodríguez (Ceuta 1926, Madrid 2001), a Spanish sculptor and painter. He has worked with different materials depending on the message of his artwork; among them, steel was the first material he used. Once Módulo was performed in 1971 during his rationalist period, while he was studying different geometry forms (Gómez, 2016) which are expressed in this artwork [figure 1]. The sculpture is a cube with dimensions of $160 \mathrm{~cm}$. each side made of WS with circular shapes inside. It was acquired by the Museo Nacional Centro de Arte Reina Sofía in 1971 and deposited at the Museo de Escultura al Aire Libre de Leganés (Madrid) in 2000-2001.

The aim of this work is to analyze the protective ability of the sculpture patina in areas with different time of wetness and different visual surface heterogeneities to study the effect that it may have on the development of the rust.

\section{Methodology}

\section{-1 . Zones of analysis}

The sculpture Once Módulo is placed at the Museo de Escultura de Leganés (south of Madrid, Spain). The museum is outdoors and inside of a park. The environment could be classified as urban atmosphere of corrosivity category C2 for plain carbon steel, according to ISO 9223. The sculpture has a complex geometry with areas of different time of wetness. Two of these areas were chosen for analysis: a vertical one labeled as Normal zone and another area labeled as Sheltered zone with less exposure to rainwater. In the vertical area it is possible to distinguish differences in color and texture in the patina, so a third zone was chosen in this area and labeled as Irregular zone. The three zones of analysis are shown in [figure 2]. Although the number of measurements is low for statistical purposes, in this work only comparative study has been taken into account.
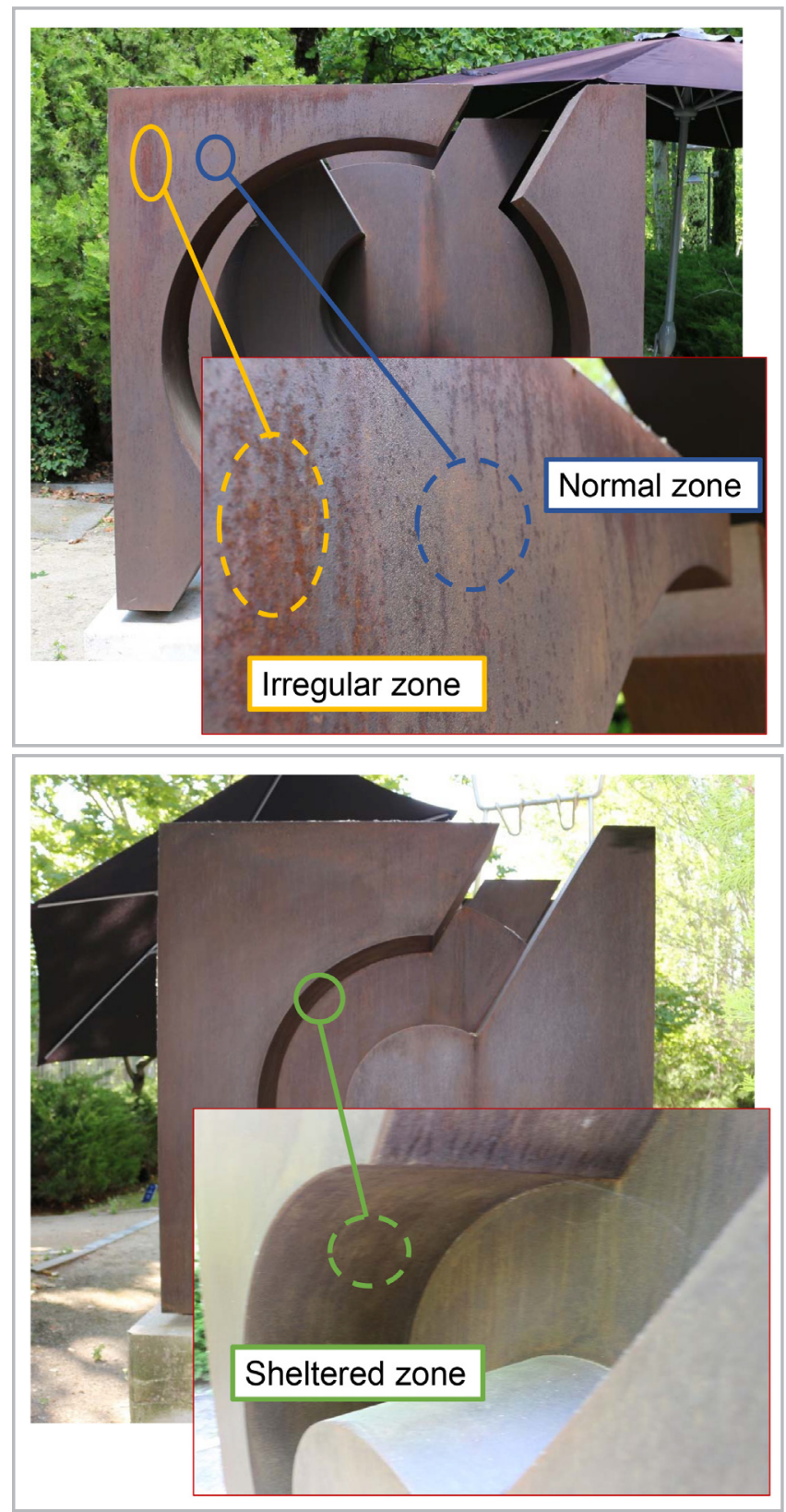

Figure 2.- Details of the three zones of analysis (solid circles) and magnifications (dashed circles). Normal zone (blue), Irregular zone (yellow) and Sheltered zone (green). 


\section{-2. Techniques}

The protective ability of the rust in the different areas of the sculpture was measured by Electrochemical Impedance Spectroscopy (EIS). EIS is a very useful technique because it provides information about the corrosion process as well as the protective behavior of the patina, however its application for in situ analysis is complicated due to the difficulties of placing an electrochemical cell with a liquid electrolyte on the usually curved, rough and non-vertical surfaces of the sculptures (Ramírez Barat and Cano, 2018). To perform EIS analysis directly over the patina of the metallic sculpture, a portable electrochemical cell was designed (Cano et al., 2014, Ramírez Barat et al., 2018). In this study, the electrochemical cell consists of a stainlesssteel mesh as counter electrode, a Ag/AgCl electrode as a reference and the electrolyte is an artificial rain prepared in the laboratory according to the pollutants of Madrid; the electrolyte was gelled with 3\% agar. EIS analysis have been performed with a Gamry Reference 600 potentiostat, the sequence applied was 1800 seconds of Open Circuit Potential (OCP) and EIS from $100 \mathrm{kHz}$ to 10 $\mathrm{mHz}$ with an amplitude of $10 \mathrm{mV}$. The fit of the results was made with Zview software.

EIS results have been analyzed with reference to the patina thickness, which has been measured with an Elcometer 456 gauge, using a probe for ferrous materials in the same areas tested for EIS.

Finally, as aesthetical properties are a matter of importance in cultural heritage, color has been measured in the same areas with a Konica Minolta spectrophotometer CM-700-d. Differences between two colors are a subjective matter, but a way to measure them is with the parameter $\Delta \mathrm{E}$ calculated with the differences in the CIEL*a*b* sphere coordinates with the following formula.

$$
\Delta E=\sqrt{ }\left(\Delta L^{2}+\Delta a^{2}+\Delta b^{2}\right)
$$

To evaluate the differences in color, the previous formula has been applied. Variation of the $L^{*}$ parameter (brightness) and $\mathrm{a}^{*}$ and $\mathrm{b}^{*}$ parameters (green- yellow and blue-red axes respectively) have been calculated for the three measured zones, therefore, it is possible to compare the color obtained in the three zones of analysis among each other.

\section{Results and discussion}

\section{-1. Electrochemical impedance spectroscopy}

To obtain information about the measured systems it is useful to fit the results to an equivalent circuit. The equivalent circuit provides information of each electrical component, which can be associated with the different parts of the measured system. Fitting is not an easy task, many equivalent circuits have been tested but the best results and physical meaning were obtained with the one proposed by Dhaiveegan et al. (2014) and shown in figure 3.

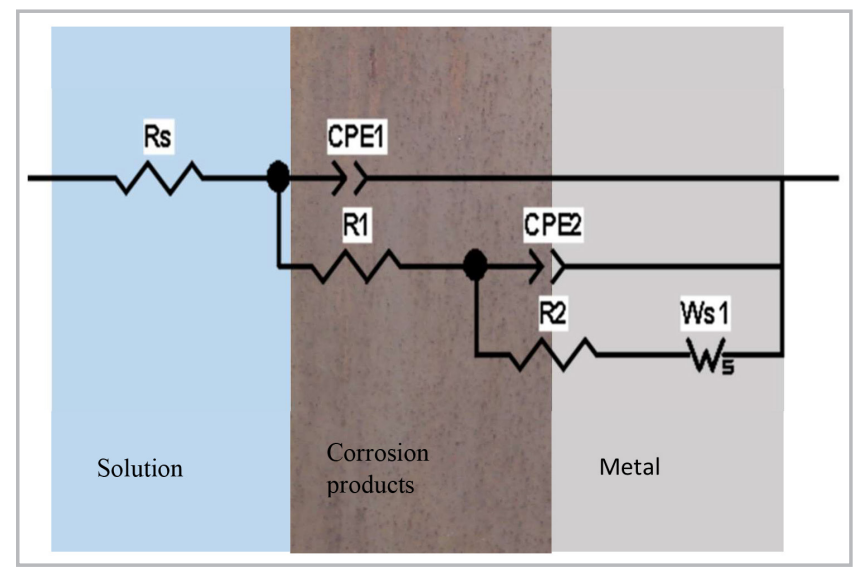

Figure 3.- Equivalent circuit proposed and its representation in the corrosion layer.

In the equivalent circuit, Rs represents the ohmic drop; CPE1 and R1 are the constant phase element and the resistance of the corrosion products respectively; CPE2 and $\mathrm{R} 2$ represent the constant phase element associated to the electrochemical double layer and the charge transfer resistance of the corrosion process; and Ws is the Warburg impedance associated with diffusion of the species through the diffusion layer. In this work we are going to focus on the resistance of the corrosion products (R1) and the charge transfer resistance (R2) in the three zones of analysis. Representative EIS results are shown in table 1 and experimental data together with the respective fittings are shown in figure 4 .

The different fittings show a very good Chi square as well as a good fit in the graphs. The resistances of the corrosion products (R1) have low errors although the resistances of the charge transfer process (R2) have higher errors. All errors are acceptable, even for the R2 for the Sheltered zone, the higher error, it is lower than the differences between different zones.

According to the results of the resistance of the corrosion products (R1), the Normal zone has a resistance value that is approximately twice the other two zones (the

Table 1.- Resistances of the equivalent circuit obtained for the three analyzed areas of the sculpture Once Módulo

\begin{tabular}{|l|c|c|c|c|c|}
\hline & $\begin{array}{c}\text { R1 } \\
(\mathrm{Ohm})\end{array}$ & $\begin{array}{c}\mathrm{R} 1 \\
\text { error } \\
(\%)\end{array}$ & $\begin{array}{c}\mathrm{R} 2 \\
(\mathrm{Ohm})\end{array}$ & $\begin{array}{c}\mathrm{R} 2 \\
\text { error } \\
(\%)\end{array}$ & $\begin{array}{c}\text { Chi } \\
\text { square }\end{array}$ \\
\hline Normal zone & 894.8 & 1.03 & 1637 & 24.29 & $4.39 \mathrm{E}-4$ \\
\hline Irregular zone & 417.3 & 0.43 & 1005 & 22.67 & $6.95 \mathrm{E}-5$ \\
\hline Sheltered zone & 428.3 & 10.02 & 240.9 & 61.22 & $1.35 \mathrm{E}-4$ \\
\hline
\end{tabular}



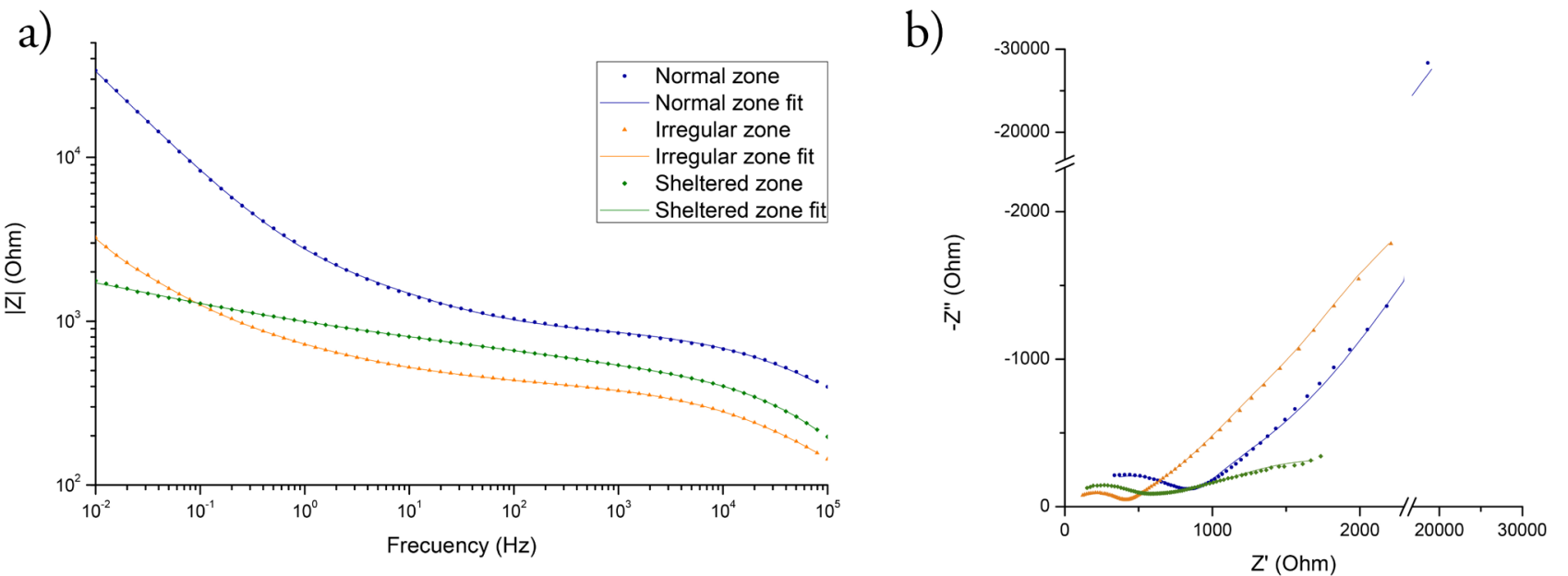

Figure 4.- Impedance module plot (a) and Nyquist plot (b) for the three zones of analysis of the sculpture Once Módulo.

Irregular and the Sheltered). This fact indicates that the corrosion products have a higher protective effect in this area.

The Irregular and Sheltered zones have very similar values of $\mathrm{R} 1$ so this two corrosion layers have similar protective properties. The charge transfer resistance (R2) is also higher in the Normal zone, with Sheltered zone being the least resistant. Results show a better protective ability in the Normal zone while the Sheltered zone is more susceptible to suffer corrosion processes.

Results do not necessary indicates that the sculpture Once Módulo is at risk but that there are areas within the sculpture that are more susceptible to atmospheric corrosion. The artwork is placed outdoors in a park of Leganés with probably little pollution, which suggests that the environment is optimal for this material (Morcillo et al., 2019).Therefore, at the time the analysis were made, there is no need to think that the sculpture is at any kind of risk that may compromise its conservation.

\section{-2. Thickness}

The thickness of the patina was measured in fifteen different points in each of the three analyzed areas. The average thickness and standard deviation are shown in table 2 .

Table 2.- Results of patina thickness for the three analyzed areas in the sculpture Once Módulo.

\begin{tabular}{|c|c|c|}
\hline Normal zone $(\mu \mathrm{m})$ & Irregular zone $(\mu \mathrm{m})$ & Sheltered zone $(\mu \mathrm{m})$ \\
\hline $103.7 \pm 21.88$ & $56.7 \pm 9.46$ & $43.1 \pm 7.21$ \\
\hline
\end{tabular}

The Normal zone has close to the double of the thickness than the other two areas, which is in accordance with the higher resistance shown by EIS results of the corrosion layer (R1). Although the Irregular zone had a rough aspect and was expected to be thicker, the thickness of its patina is more similar to the Sheltered zone than to the Normal zone. Authors have measured the thickness of their own hair following the experiment performed by (Diez, 2015), values between 50 and $60 \mu \mathrm{m}$ were obtained. Although these patinas are very thin, there is not much difference from a patina developed for five years in a rural environment (Díaz et al., 2018). This indicates that the corrosivity of the environment of the park in the Museum is low.

The results of the resistance of the corrosion products are in agreement with the patina thickness and indicate that, although the Normal and the Irregular zone are very close in the sculpture and have same exposure to rainwater, they have notable differences in their behavior against atmospheric corrosion. The Sheltered zone, with less time of wetness, has the poorest protection against atmospheric corrosion but, as mentioned above, its risk to suffer severe atmospheric corrosion processes will depend on the environment.

\section{-3. Color}

Color has been analyzed in fifteen different points around the zone of analysis. Results are reported using the $C I E L^{*} a^{*} b^{*}$ sphere where $L^{*}$ parameter represents the luminosity (being the value 100 white and 0 black) and the $a^{*}$ and $b^{*}$ parameters represents the content in green (negative $a^{*}$ ) and red (positive $a^{*}$ ) and the content of blue (negative $b^{*}$ ) and yellow (positive $b^{*}$ ). Results are shown in table 3 and in figure 5 . 
Table 3.- $L^{*} a * b *$ results for the three zones of analysis.

\begin{tabular}{|l|c|c|c|}
\hline & $\mathrm{L}^{*}$ & $\mathrm{a}^{*}$ & $\mathrm{~b}^{*}$ \\
\hline Normal zone & $32.4 \pm 0.4$ & $4.9 \pm 0.7$ & $5.3 \pm 1.3$ \\
\hline Irregular zone & $27.0 \pm 1.7$ & $8.3 \pm 0.8$ & $7.0 \pm 0.7$ \\
\hline Sheltered zone & $35.2 \pm 0.7$ & $5.4 \pm 0.3$ & $8.2 \pm 0.4$ \\
\hline
\end{tabular}

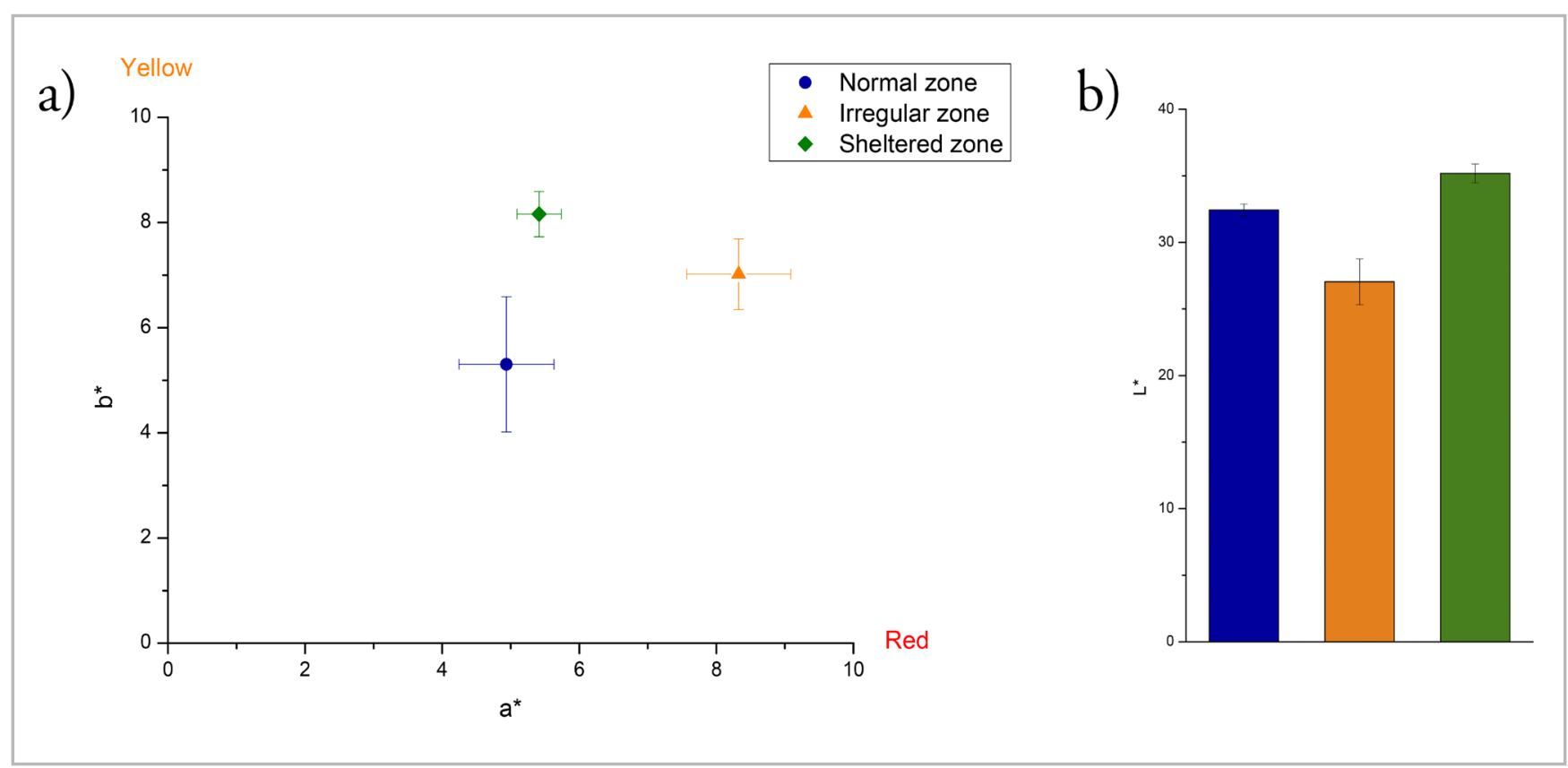

Figure 5.- Chromatic parameters $a^{*}$ and $b^{*}(a)$ and luminosity parameter $L^{*}(b)$.

As $a^{*}$ and $b^{*}$ have positive values it means that the tone of the patina tends to orange, however the values are quite low, so the colors are dull. Also, the $L^{*}$ values are closer to the center of the sphere (50), so the colors are grayish and weak. Comparing the three zones of analysis, the Irregular zone has higher values in parameters $a^{*}$ and $b^{*}$ and a lower value of $L^{*}$, it is the most vivid color with a darker tone. Data of color differences $\Delta \mathrm{E}$ between the three zones of analysis are shown in table 4.

According to the bibliography, if $\Delta \mathrm{E}$ is higher than 1 (Ghelardi et al., 2015) the color differences are perceptible for the human eye. In the case of study all the zones have differences much greater than 1, being the Irregular zone the most different one with a $\Delta \mathrm{E}=6.6$ with the Normal zone and $\Delta \mathrm{E}=8.7$ with the Sheltered zone. This is in accordance with initial observations as this area was analyzed due to the differences in a visual inspection. According to the EIS analysis, in this case, the visual differences are related to different protective abilities against corrosion.

\section{Conclusions}

The use of WS in cultural heritage has some peculiarities that have to take into account; among them, the design of the sculptures may yield differences in the protective ability of the patinas. It has been proved that Sheltered zones develop the less protective corrosion products although the risk to suffer damage will depend on the atmosphere to which it is exposed. In this case of study and at the time analysis were performed, there is no risk for the sculpture due to the low pollution of the atmosphere.

Table 4.- $\Delta E$ results of the three areas of analysis in the sculpture Once Módulo

\begin{tabular}{|l|c|c|c|}
\hline$\Delta \mathrm{E}$ & Normal zone & Irregular zone & Sheltered zone \\
\hline Normal zone & - & 6.60 & 3.99 \\
\hline Irregular zone & 6.60 & - & 8.72 \\
\hline Sheltered zone & 3.99 & 8.72 & - \\
\hline
\end{tabular}


Under a visual analysis, some heterogeneities are evident in the surface and may be related to less protection against corrosion. Changes in color and thickness have reveal differences in the protective characteristics of the rust. A full documentation of the history of the artworks and a complete study of the sculptures are necessary in order to assure the preservation of WS.

\section{Acknowledgments}

Authors acknowledge Juan Carlos Roldán for his work in field measurements and his work with audiovisual material. Rosa María Izquierdo from the Museo de Escultura de Leganés and Pilar García from the Museo Nacional Centro de Arte Reina Sofia for their kind support and patience. And to the Agencia Estatal de Investigación for the grant BES-2015071472 and to Comunidad de Madrid for the project TOPHERITAGE CM (S2018/NMT_4372) for financial support.

\section{References}

CANO, E., CRESPO, A., LAFUENTE, D., RAMIREZ BARAT, B. (2014). "A novel gel polymer electrolyte cell for in-situ application of corrosion electrochemical techniques". Electrochemistry Communications, 41:16-19. https://doi.org/10.1016/j.elecom.2014.01.016

CRESPO, A. RAMÍREZ-BARAT., B. CANO, E. (2016).“Artificial patinas in contemporary weathering steel sculpture". In International Conference YOCOCU. V International Conference of Youth in Conservation of Cultural heritage. Madrid.

DHAIVEEGAN, P., ELANGOVAN, N., NISHIMURA, T., RAJENDRAN, N. (2014). "Electrochemical Characterization of Carbon and Weathering Steels Corrosion Products to Determine the Protective Ability Using Carbon Paste Electrode (CPE)". Electroanalysis, 26, 2419-2428. https://doi.org/10.1002/elan.201400240

DÍAZ, I., CANO, H., CHICO, B., DE LA FUENTE, D., MORCILLO, M. (2012). "Some clarifications regarding literature on atmospheric corrosion of weathering steels". International Journal of Corrosion, 2012. https://doi.org/10.1155/2012/812192

DÍAZ, I., CANO, H., CRESPO, D., CHICO, B., DE LA FUENTE, D. MORCILLO, M. (2018). "Atmospheric corrosion of ASTM A-242 and ASTM A-588 weathering steels in different types of atmosphere". Corrosion Engineering Science and Technology, 53: 449-459. https://doi.org/10.1080/1478422X.2018.1500978

DIEZ, A. (2015). Cómo medir el grosor de un pelo usando un láser casero [Online]. https://www.elespanol.com/omicrono/ tecnologia/20150425/medir-grosor-pelo-usando-lasercasero/28497157 0.html: El Español. [Accessed 07/03 2017].

GHELARDI, E., DEGANO, I., COLOMBINI, M. P., MAZUREK, J., SCHILLING, M., KHANJIAN, H., LEARNER, T. (2015). "A multianalytical study on the photochemical degradation of synthetic organic pigments". Dyes and Pigments, 123: 396-403.
GÓMEZ, P. (2016). Amador Rodríguez Menéndez [Online]. http:// www.esculturaurbana.com/paginas/ama.htm\#p). [Accessed 21/10 2019].

MORCILLO, M., CHICO, B., DÍAZ, I., CANO, H., DE LA FUENTE, D. (2013). "Atmospheric corrosion data of weathering steels. A review". Corrosion Science, 77: 6-24. https://doi.org/10.1016/j. corsci.2013.08.021

MORCILLO, M., DÍAZ, I., CANO, H., CHICO, B., DE LA FUENTE, D. (2019). "Atmospheric corrosion of weathering steels. Overview for engineers. Part I: Basic concepts". Construction and Building Materials, 213: 723-737. https://doi.org/10.1016/j. conbuildmat.2019.03.334

RAMÍREZ BARAT, B., CANO, E. (2018). "In Situ Electrochemical Impedance Spectroscopy Measurements and their Interpretation for the Diagnostic of Metallic Cultural Heritage: A Review". ChemElectroChem, 5: 2698-2716.

RAMÍREZ BARAT, B., CANO, E., LETARDI, P. (2018). "Advances in the design of a gel-cell electrochemical sensor for corrosion measurements on metallic cultural heritage". Sensors and Actuators, B: Chemical, 261: 572-580.

SCOTT, J. (1991). "Conservation of weathering steel sculpture". In: Saving the twentieth century: the degradation and conservation of modern materials, Ottawa, Canada. Canadian Conservation Institue.

STRATMANN, M., BOHNENKAMP, K., ENGELL, H. J. (1983). "An electrochemical study of phase-transitions in rust layers". Corrosion Science, 23: 969-985. https://doi.org/10.1016/0010$\underline{938 \times(83) 90024-0}$

\section{Author/s}

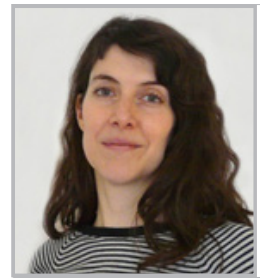

\section{Ana Crespo Ibáñez}

a.crespoibanez@cenim.csic.es

Centro Nacional de Investigaciones Metalúrgicas (CENIM) - Consejo Superior de Investigaciones Científicas (CSIC)

Ana Crespo obtained her bachelor degree in Chemistry with specialization in Chemistry of Materials in 2011 from the Complutense University of Madrid. During her bachelor she started the study of materials in cultural heritage with the project "Spectroscopic analysis of additives of concrete" at the Institute for the Structure of Matter. She continued her academic training with the master degree in Materials Science and Engineering in 2013 from Carlos III University of Madrid, where she obtained the award of basic science and engineering for the design of a portable electrochemical cell with gel-electrolyte, carried out at the CENIM. After working in the UK she returned to Spain to start her PhD at the CENIM with the project "Characterization and evaluation of artificial patinas in weathering steel sculpture". Her work is focused on the study of natural and artificial patinas in weathering steel sculpture with Raman spectroscopy and 
electrochemical techniques. During her PhD she made an internship at Commissariat à l'energie atomique de Saclay (France) studying Raman mapping and EDS analysis in rust; she has participated in 8 national and international projects, 1 of them as principal investigator at the synchrotron SOLEIL; 8 publications in congress, 7 of them international; she has collaborated in specialized training courses and postgraduate courses with Carlos III University of Madrid, Pablo de Olavide University of Seville, Menéndez Pelayo International University. She is currently writing her PhD thesis that hopefully will be finished at June 2020 .

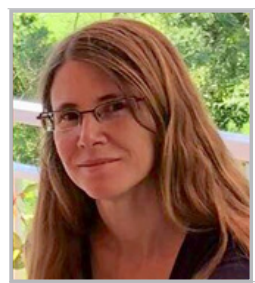

\section{Blanca Ramírez Barat}

blanca.ramirez@csic.es

Centro Nacional de Investigaciones Metalúrgicas (CENIM) - Consejo Superior de Investigaciones Científicas (CSIC)

Postdoctoral researcher in the group "Corrosion and Protection of Metals in Cultural Heritage and Construction (COPAC)" at the Nacional Centre for Metallurgical Research (CENIM-CSIC), Madrid, Spain. After receiving her BA in Fine Arts (conservation), she graduated in Chemistry at the Complutense University in Madrid and completed her PhD in Materials Science and Engineering at the Carlos III University in Madrid. Her research is focused in the application of electrochemical techniques for conservation assessment and diagnosis in metallic cultural heritage and her doctoral thesis has been dedicated to the development of an electrochemical cell for in situ measurements on cultural heritage. She is also involved in several projects, networks and activities related to Heritage Science such as the Spanish Network of Science and Technology for the Conservation of Cultural Heritage (TechnoHeritage), the National Plan for Research Conservation in Cultural Heritage (PNIC), CSIC's Interdisciplinary Thematic Platform Patrimonio Abierto: Investigación y Sociedad, PTI-PAIS (Open Heritage: Research and Society) or the Spanish Node of the Research Infrastructure for Heritage Science (ERIHS.es). https://orcid.org/0000-0001-5306-4057

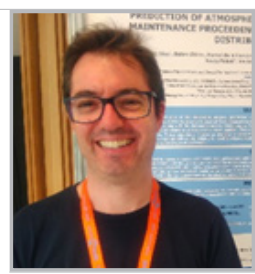

\section{Iván Díaz Ocaña \\ ivan.diaz@cenim.csic.es \\ Centro Nacional de Investigaciones Metalúrgicas (CENIM) - Consejo Superior de Investigaciones Científicas (CSIC)}

He received his Bachelor's degree in materials chemistry and his PhD, with a distinction "cum laude", from the Complutense University in Madrid. His doctoral thesis was one of the first indepth research conducted in Spain on atmospheric corrosion of weathering steels, incorporating nickel in its composition. During his $\mathrm{PhD}$, he received several pre-doctorate research scholarships to complete his training in the characterization of rust at the Old Dominion University (USA) and University of Antioquia (Colombia). He has a solid background in electrochemical and accelerated corrosion tests and its research focus is on indoor and outdoor atmospheric corrosion of metals.
As a result, he has published around 40 research papers in peerreviewed journals in the field of atmospheric corrosion and has carried out scientific-technical assistance tasks for the industry. Currently, he is working as postdoctoral researcher in the group "Corrosion and Protection of Metals in Cultural Heritage and Construction (COPAC)" at the Nacional Centre for Metallurgical Research (CENIM-CSIC), Madrid, Spain.

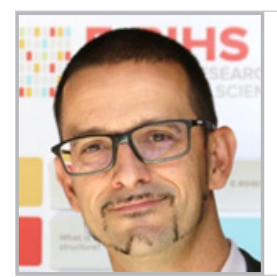

Emilio Cano
ecano@cenim.csic.es
Centro Nacional de Investigaciones
Metalúrgicas (CENIM) - Consejo Superior
de Investigaciones Científicas (CSIC)

Emilio Cano is Tenured Scientist at the National Center for Metallurgical Research (CENIM) of the Spanish National Research Council (CSIC) in Madrid, leading the research group "Corrosion and Protection of metals in cultural heritage and construction" (COPAC). He graduated in Fine Arts Conservation in 1996 and obtained his $\mathrm{PhD}$ in 2001 from the Complutense University of Madrid, after an internship at the Canadian Conservation Institute (CCl), Ottawa. As heritage scientist, his work has focused in the study of corrosion and protective systems for the metallic Cultural Heritage, atmospheric corrosion in museums and exhibitions; and the application of electrochemical techniques and corrosion inhibitors for the conservation of the cultural heritage. He has published more than 125 scientific articles (88 in JCR/Scopus indexed journals), and presented at more than 100 scientific conferences. He has participated in 33 national and international research projects (6th and 7th Framework Programmes and Horizon 2020 from the EU), being PI in 14 of them in the last 10 years. These projects and several research contracts have been developed in collaboration with the most relevant institutions working on conservation of cultural heritage (Instituto del Patrimonio Cultural de España, Patrimonio Nacional, Museo del Prado, Museo Guggenheim Bilbao, Museo Arqueológico Nacional, Museo Nacional de Ciencia y Tecnología, etc.). Spanish Representative in the Executive Board of the Joint Programming Initiative "Cultural Heritage and Global Change: a Challenge for Europe" from 2011-2017. Assistant Coordinator of the International Council of Museums-Conservation Committee (ICOM-CC) Metal Working Group since 2012; Coordinator of the Spanish Network for Science and Technology for the Conservation of Cultural Heritage (Technoheritage) since 2015, Fellow of the International Institute of Conservation (IIC) and member of the Spanish group of the IIC (GE-IIC); coordinator of the Spanish Node of the European Research Infrastructure on Heritage Science (E-RIHS). https://orcid.org/0000-0002-8716-3931

http://www.cenim.csic.es/index.php/presentacion-copac

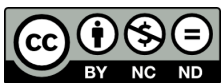

https://doi.org/10.37558/gec.v17i1.761 